\title{
Iklan mi instan di televisi pada saat pandemi Covid-19
}

\author{
Aceng Abdullah ${ }^{1}$, Rangga Saptya Mohamad Permana ${ }^{2}$ \\ ${ }^{1,2}$ Universitas Padjadjaran, Bandung, Indonesia
}

\begin{abstract}
ABSTRAK
Covid-19 memasuki Indonesia sejak trimester pertama 2020 dan pemerintah menganjurkan masyarakat "Di Rumah Saja". Salah satu kegiatan di rumah adalah menonton televisi dan produk yang sering diiklankan melalui televisi adalah mi instan. Tujuan penelitian ini adalah untuk mengetahui makna denotasi iklan mi instan di televisi, makna konotasi iklan mi instan, dan mitos pada tayangan iklan mi instan pada saat pandemi Covid-19. Penelitian ini menggunakan metode penelitian kualitatif melalui teknik analisis semiotika Roland Barthes. Pengumpulan data dilakukan melalui observasi dan teknik pendokumentasian pada bulan April 2020 pada iklan mi instan merek Indomie (tiga iklan), Mie Sedaap (tiga iklan), dan Mie Sukses's (satu iklan). Hasil penelitian menunjukkan bahwa secara denotatif, iklan Indomie mengandalkan visualisasi sederhana, hemat kata, dan tidak terlalu bombastis. Iklan Mie Sedaap dan Mie Sukses's mengandalkan deskripsi informasi produk dengan berbagai narasi panjang. Secara konotatif, iklan Indomie sesuai dengan kondisi ketika pandemi dengan fokus pada jargon "di rumah saja” sedangkan iklan Mie Sedaap dan Mie Sukses's sebaliknya menyiratkan bahwa meskipun sedang dalam kondisi pandemi, aktivitas outdoor masih bisa dilakukan dan pandemi Covid-19 tidak perlu ditakuti. Sesuai tataran mitos, iklan Indomie menggambarkan bahwa orang dengan tingkat ekonomi atas takut dengan Covid-19, iklan Mie Sedaap menggambarkan Korea Selatan berhasil mengatasi pandemi Covid-19, dan iklan Mie Sukses's menunjukkan bahwa orang dengan tingkat ekonomi bawah tidak akan terjangkit Covid-19.
\end{abstract}

Kata-kata Kunci: Iklan; televisi; mi instan; semiotika Roland Barthes; pandemi Covid-19

\section{Instant noodle advertisement on television during the Covid-19 pandemic}

\begin{abstract}
Covid-19 entered Indonesia in the first trimester of 2020, and the government has advised people to "stay at home" to minimize its spread ever since. One of the activities that many people do at home is watching television, including watching advertisements. The instant noodles advertisement is one product from many. There were three objectives of this study. First, it is to determine the denotation of the instant noodle advertisements during the Covid-19 pandemic. Second, it is to acknowledge the connotation meaning, and the last is to recognize the myths. This study used a qualitative research method through Roland Barthes' semiotic analysis technique. The instant noodle advertisements studied consisted of three brands. They are Indomie advertisements (three advertisements), Mie Sedaap (three advertisements), and Mie Sukses's (one advertisement). Data collection was carried out by observation and documentation techniques in April 2020. The results showed that Indomie advertisements rely on simple visualization, efficient words and are not too bombastic. In contrast, Mie Sedaap and Mie Sukses' advertisements rely on product information descriptions with various long narratives. In connotative terms, Indomie advertisements implied real-time conditions during the pandemic. It used the jargon "at home”. In comparison, Mie Sedaap and Mie Sukses's advertisements were the opposite. It meant that even though it was in a pandemic condition, people could still do outdoor activities. It also indicated that people did not need to be afraid of the Covid-19 pandemic. On the mythical level, Indomie's advertisement depicts that people with upper economic levels are fearful of the Covid-19. Mie Sedaap advertisement represented that South Korea had successfully overcome the Covid-19 pandemic. Mie Sukses's advertisement showed that people with lower economic levels would not be infected with Covid-19.
\end{abstract}

Keywords: Advertisement; television; instant noodle; Roland Barthes'semiotic; the Covid-19 pandemic

Korespondensi: Dr. Aceng Abdullah, M.Si. Fakultas Ilmu Komunikasi, Universitas Padjadjaran. Jalan Raya Bandung-Sumedang KM. 21 Jatinangor 45363.Email: aceng.abdullah@unpad.ac.id 


\section{PENDAHULUAN}

Dunia digoncangkan Coronavirus Disease (Covid-19) yang menyebar ke seluruh penjuru dengan amat cepat termasuk ke Indonesia. Penyebarannya sangat masif sehingga banyak orang tertular bahkan mengalami kematian. Setiap negara telah melakukan kontrol informasi untuk menginformasikan risiko dalam mencegah penularaan virus tersebut dengan cara yang beragam sesuai dengan situasi dan kondisi yang berkembang di negara masingmasing (Rosfiantika, Permana \& Mahameruaji, 2020).

Salah satu cara untuk memutus mata rantai penyebaran Covid-19 yakni semua orang diminta untuk tidak melakukan interaksi dengan siapa pun selama 12 hari, sampai virus itu mati sendiri oleh imunitas orang yang terpapar. Namun, ajakan pemerintah Indonesia kepada masyarakat untuk berdiam di rumah tidak sepenuhnya dilaksanakan, akibatnya penyebaran virus terus berlangsung. Oleh karena itu, beberapa kepala daerah yang daerahnya menjadi kawasan pandemik meminta kepada pemerintah pusat agar diijinkan melaksanakan Pembatasan Sosial Berskala Besar (PSBB). Di mana daerah tersebut menjadi daerah tertutup dan orang luar daerah tidak diperbolehkan masuk dan sebaliknya warga di sana pun tidak diijinkan untuk ke luar daerah.
Pemerintah maupun swadaya masyarakat dalam menyukseskan program "Di Rumah Saja" (Stay at Home) telah melakukan berbagai kampanye. Bahkan, hampir semua elemen masyarakat melakukan karantina melalui isolasi mandiri di komplek perumahan tempat mereka tinggal dengan memasang portal. Semua pihak mengunci diri atau populer dengan istilah lockdown. Pemerintah pun melakukan pengawasan agar setiap orang tidak bekumpul atau bergerombol lebih dari dua orang, bahkan melarang orang untuk keluar rumah jika tidak amat sangat terpaksa.

Berdiam diri di rumah bukan perkara gampang. Bagi sebagian anggota masyarakat khususnya kepala keluarga yang berprofesi di sektor informal, berdiam diri di rumah sama dengan tidak makan. Begitu pun dengan anggota keluarga ketika berdiam di rumah terus menerus dapat mendatangkan kebosanan. Maka, masyarakat untuk berdiam di rumah memerlukan hiburan. Masyarakat dapat berselancar di dunia maya dan menonton televisi sebagai hiburan di rumah. Acara televisi menjadi salah satu saluran hiburan untuk menghilangkan rasa bosan yang mudah diakses pelbagai kalangan masyarakat. Media televisi pun hingga kini masih menjadi media massa yang digunakan oleh masyarakat Indonesia dibandingkan media massa cetak yang tirasnya dalam beberapa tahun terakhir ini terus menurun drastis. Salah satu alasannya 
adalah dari segi penyebaran informasi, televisi menjadi media yang lebih atraktif dan lebih aktual dibandingkan media cetak dalam menyiarkan informasi yang terjadi (Permana, Abdullah, Mahameruaji, 2019).

Adapun masyarakat ketika menonton televisi seringkali melihat tayangan di layar televisi berupa tayangan iklan. Bagi semua stasiun (kecuali televisi publik), iklan menjadi tumpuan utama pada industri televisi. Sebaliknya, bagi sebagian besar kalangan bisnis mengiklankan produknya di media televisi menjadi tumpuan utama untuk mempromosikan produk. Walaupun kalangan pebisnis pun menggunakan media online yang kini dijadikan sebagai media promosi alternatif. Produsen memengaruhi alam bawah sadar khalayak mengenai produknya lewat iklan sehingga tercipta realitas yang menjadi standar (Worotitjan, 2014).

Maka, adanya persaingan yang sengit antar produsen untuk memperebutkan pangsa pasar melalui agensi membuat mereka harus berpikir keras bagaimana memproduksi sebuah tayangan iklan yang menarik perhatian penonton sehingga efektivitas promosinya sesuai harapan. Khalayak sebelum memutuskan untuk membeli sebuah produk terkadang ingin memastikan dulu mutu dan menarik tidaknya produk tersebut. Iklan dapat digunakan sebagai media untuk mencapai tujuan tersebut. Di samping itu, iklan merupakan salah satu medium pesan yang cukup efektif untuk mempromosikan sebuah produk (Indriani, Puspitasari, \& Rosfiantika, 2019).

Iklan televisi menjadi ruh utama bagi sebuah stasiun televisi karena hidup matinya sebuah stasiun televisi khususnya stasiun televisi swasta sangat tergantung dari iklan komersial yang dipasang pihak agensi kepada stasiun televisi tersebut. Maka semakin banyak iklan yang dipasang, semakin besar pula pemasukan bagi stasiun televisi tersebut. Iklan semakin banyak yang masuk ke sebuah stasiun televisi maka semakin memungkinkan bagi sebuah stasiun televisi untuk memproduksi acara yang bagus.

Iklan televisi di hampir semua penjuru dunia umumnya berdasarkan menarik tidaknya acara yang ditampilkan bagi khalayak. Khalayak yang memiliki minat yang besar untuk menonton televisi, maka semakin besar kemungkinan iklan akan dipasang pada acara tersebut. Media biasanya "menjual" khalayaknya dalam bentuk rating atau share kepada pengiklan untuk dapat menggunakan waktu tayang mereka (Sari, 2020)

Iklan pun di sebagian besar negara di dunia, ditayangkan di televisi tergantung rating dan share hasil riset lembaga komersial. Semakin tinggi nilai rating dan share sebuah acara, maka semakin tinggi pula peluang iklan untuk bisa 
ditampilkan di sebuah stasiun televisi.

Salah satu produk yang diiklankan melalui media televisi adalah mi instan. Iklan mi instan hampir setiap hari muncul di layar televisi sejak televisi swasta berdiri di Indonesia, bahkan pada zaman TVRI dasawarsa 80 -an iklan mi instan sudah ada. Hal tersebut menunjukkan bahwa mi instan sudah menjadi keseharian masyarakat Indonesia. Menurut World Instant Noodles Association pada tahun 2018, tingkat konsumsi mi instan di Indonesia menempati posisi kedua teratas dari seluruh dunia dengan konsumsi 12,52 miliar porsi. Hanya China yang tingkat konsumsi mi instannya lebih tinggi dari Indonesia (Sandra \& Setyabudi, 2020).

Produk mi instan yang dipromosikan dibuat beragam sesuai varian rasa mi yang diproduksi. Selain itu, persaingan bisnis mi instan ternyata sangat ketat sehingga ragam iklan yang ditampilkan pun dirancang semenarik mungkin. Bahkan untuk merek baru tak jarang dipromosikan melalui selebriti terkenal, baik selebriti tingkat nasional maupun internasional. Hal ini dikenal dengan istilah celebrity endorser. Selebriti digunakan sebagai figur penarik perhatian iklan. Hal ini merupakan salah satu cara kreatif untuk menyampaikan pesan. Pesan yang disampaikan selebriti akan lebih mudah dan menarik perhatian konsumen (Savitri, 2017).

Penulis meneliti iklan mi instan di tengah pandemi Covid-19 berdasarkan empat alasan. Pertama, penyebaran Covid-19 tidak lepas penyebarannya melalui interaksi antar manusia. Kedua, virus Covid-19 menyerang manusia setelah masuk melalui rongga mulut atau hidung sehingga makanan merupakan produk yang harus bersih dari virus mematikan ini. Ketiga, tingginya produksi mi instan di Indonesia. Indonesia menjadi negara terbesar kedua di dunia sebagai pengonsumsi mi instan setelah Cina. Tahun 2019, konsumsi mi instan orang Indonesia mencapai 14 milyar bungkus. Keempat, iklan mi instan di televisi maupun media lainnya memiliki frekuensi tinggi dan menjadi empat besar komoditas yang paling sering ditayangkan sebagai iklan televisi.

Masyarakat Indonesia mengonsumsi mi instan sangat tinggi dapat disebabkan promosi melalui media televisi yang ditonton jutaan orang setiap hari termasuk saat Covid-19 mewabah di tanah air. Lalu yang menjadi pertanyaan peneliti ialah apakah visualisasi iklan mi instan tersebut sudah sejalan dengan ajakan gerakan memutus rantai penyebaran Covid-19 atau tidak.

Adapun terdapat lima merek (brand) iklan yang paling banyak mengeluarkan belanja iklan di antaranya Indomie, Mie Sedaap, Sarimi, Roma, dan Pop Mie. Indomie mengeluarkan belanja iklan sebesar Rp. 883,38 miliar; Mie Sedaap dan Sarimi di posisi kedua dan ketiga 
dengan belanja iklan masing-masing Rp. 810,64 miliar dan Rp. 716,42 miliar. Selanjutnya, Roma menghabiskan Rp. 595,64 dan Pop Mie sebesar Rp.574,86 miliar (Wulandari, 2019). Sesuai data ini, terlihat bahwa belanja iklan tiap merek memiliki harga yang tinggi.

Berdasarkan iklan di televisi yang sering dimunculkan ternyata akan memunculkan berbagai penafsiran makna. Gambar atau tanda bukanlah hanya dimaknai secara realitas tetapi dapat memunculkan makna baru bagi khalayaknya yang bersifat konotatif. Hal ini selanjutnya memunculkan anggapan tertentu yang belum tentu dapat dibuktikan kebenarannya yang seringkali disebut sebagai mitos (Barthes, 2017). Selain itu, iklan televisi dalam beberapa iklan tidak jarang pula memperlihatkan sarat makna laten atas pemihakan pesan iklan kepada kelompok tertentu atau pada kelas yang berkuasa atau dominan (Umarela, Dwityas, \& Zahra, 2020). Berdasarkan hal tersebut, peneliti dalam membedah iklan televisi pada mi instan Indomie, Mie Sedaap, dan Mie Sukses's, menggunakan pisau analisis semiotika Barthes (2017), melalui analisis gambar atau visual dari sisi denotasi, konotasi, dan mitos. Adapun penelitian ini memiliki tujuan untuk mengetahui makna denotasi iklan mi instan di televisi pada saat pandemi Covid-19, untuk mengetahui makna konotasi iklan mi instan pada saat pandemi Covid-19, dan ntuk mengetahui mitos pada tayangan iklan mi instan pada saat pandemi Covid-19.

\section{METODE PENELITIAN}

Penelitian ini menggunakan metode penelitian kualitatif dengan teknik analisis semiotika Roland Barthes. Semiotika Roland Barthes digunakan untuk menganalisis media berdasarkan asumsi bahwa media dikomunikasikan melalui seperangkat tanda (Yuliyanti, Bajari, \& Mulyana, 2017). Hal ini dilakukan karena alam proses komunikasi terjadi pertukaran pesan, di mana tanda merupakan bagian dari pesan tersebut.

Semiotika sering juga disebut ilmu tentang tanda. Semiotika pun berkembang menjadi studi tentang makna visual berdasarkan fenomena atau peristiwa sebelumnya yang memunculkan makna. Metode ini dipilih karena semiotika mampu memberikan ruang yang lebih luas dalam melakukan interpretasi objek visual sehingga peneliti mampu menemukan makna yang tersembunyi di dalamnya. Analisis semiotika ini pun bersifat interpretatif kualitatif. Maka secara umum teknik analisis datanya mirip prosedur metode penelitian kualitatif, yaitu diawali dengan melakukan identifikasi objek visual yang diteliti lalu dianalisis dan kemudian ditafsirkan maknanya (Denzin \& Lincoln, 2017).

Ada 3 komponen penilaian dari Barthes 
(2017) di antaranya komponen denotasi, konotasi, dan mitos. Denotasi merupakan fakta apa yang terlihat oleh mata secara obyektif. Menurut Barthes (2017), konotasi merupakan turunan penafsiran dari apa yang muncul dari denotasi. Konotasi walaupun memiliki sifat asli tanda, namun untuk mengartikannya peneliti membutuhkan wawasan sesuai pengalaman seseorang. Sesuai konotasi, tanda akan memunculkan anggapan dan penafsiran baru yang kemudian disebut mitos. Barthes pun menciptakan peta tentang bagaimana tanda bekerja dan saling berkaitan (Cobley \& Jansz, 2010).

Berdasarkan pendekatan semiotika Barthes (2017), semiotika awalnya hanya digunakan untuk membedah bahasa dalam arti sempit menjadi bahasa dalam arti luas termasuk bahasa visual. Hal ini memandang ada makna lain di balik sebuah visualisasi atau gambar tertentu yakni konotasi. Barthes (2017) pun menyatakan bahwa di balik makna denotasi terdapat makna konotasi yang tersembunyi dan dari dua makna tersebut dapat memunculkan mitos bahkan ideologi. Film iklan dari kacamata Barthes (2017) di dalamnya termasuk pula sebagai pesan tanpa kode (message without a code) namun sekaligus juga sebagai pesan yang memiliki kode (message with a code) sehingga iklan televisi dapat dimaknai dengan konotasi bahkan menjadi mitos.
Oleh karena itu, semiotika Barthes acapkali disebut sebagai semiotika konotasi. Hal ini ditekankan untuk membedakan semiotika linguistik yang terlebih dahulu dikembangkan para seniornya, yakni Saussure. Konsep semiotik menurut Barthes (2017) adalah makna denotasi dan konotasi dibedakan dalam sebuah tampilan visual yang sama. Tanda konotatif tidak berdiri sendiri tetapi merupakan bagian dari tanda denotasi itu sendiri. Sementara Saussure hanya sebatas pada tanda denotasi saja. Maka konsep Barthes semakin melengkapi dan menyempurnakan pandangan semiotika Saussure (Sobur, 2017).

Berdasarkan hal di atas, sebuah pesan visual dapat dimaknai secara denotatif, konotatif, dan bagaimana mitos di balik dua makna tersebut. Untuk itu, analisis terhadap iklan mi instan di televisi pada saat pandemi Covid-19 dapat dibahas sesuai tiga unsur tadi. Peneliti dalam penelitian ini memilih beberapa iklan mi instan dari beberapa merek di antaranya merek Indomie, Mie Sedaap, dan Mie Sukses's. Tiga merek mi instan ini yang paling sering muncul pada iklan televisi pada April 2020, di mana Indonesia tengah menerapkan karantina mandiri.

Adapun obyek penelitian yang dianalisis adalah iklan mi instan yang ditayangkan di sejumlah stasiun televisi pada April 2020 pada saat Pembatasan Sosial Berskala Besar (PSBB) 
dan bertepatan pada Ramadan 1441 H. Sesuai sejumlah iklan yang memang tampilannya mirip, peneliti mengambil tiga merek mi instan berdasarkan beberapa pertimbangan. Pertama, mi instan dari merek paling terkenal dan ekspansi produknya hingga ke luar negeri dan diproduksi (pabrikasi) di sejumlah negara di Asia, Eropa, dan Afrika, yakni Indomie produksi PT. Indofood COP Sukses Makmur. Kedua, mi instan pesaing Indomie, yakni Mie Sedaap. Kehadirannya amat sangat diwaspadai Indomie, memiliki iklan sangat gencar untuk menarik simpati calon pembeli, dan membidik kaum muda yang secara statistiknya populasinya paling besar. Mie Sedaap diproduksi PT. Prakarsa Alam Segar, yang secara perlahan menangkis market share Indomie yang hadir lebih dulu dan selalu menempati posisi pertama dalam penjualan dan mampu mengungguli para "mi instan pendahulu", seperti Sarimi dan SuperMi (Sukmana, Achmad, \& ZA, 2017).
Ketiga, Mi Sukses's, sebagai mi instan yang menyasar kalangan menengah ke bawah dengan pemasaran ke pasar tradisional di pinggiran kota, bukan di supermarket dalam kota. Mi instan ini secara populasi, banyak diminati kalangan menengah ke bawah dan populasinya secara statistik terbesar di Indonesia. Mi Sukses's harganya jauh lebih murah dibandingkan dua merek di atas dan diproduksi satu grup dengan Mie Sedaap yakni PT. Prakarsa Alam Segar. Adapun objek penelitian pada iklan tiga merek mi instan ditampilkan pada kurun April 2020 dengan deskripsi judul iklan pada tabel 1.

Peneliti dalam mengumpulkan data melakukan observasi dan teknik pendokumentasian dengan cara merekam semua iklan yang diteliti. Kegiatan observasi dimulai dengan menonton iklan tiga merek mi instan yang ditayangkan di televisi pada minggu pertama April dan minggu keempat pada bulan yang sama.

\section{Tabel 1 Produk Mi dan Judul Iklan yang Diteliti}

\begin{tabular}{lcc}
\hline Nama Produk & Judul Iklan & Keterangan \\
\hline Indomie & a. "Indomie Nyaman di Rumah" & Edisi puasa \\
& b. "Indomie Mi-nya Gak Ada" & Edisi buka puasa \\
c. "Indomie Mi-nya Ada" & \\
a. "Ini Pilihan Sedaap-Ku" & \\
b. "Korean Spicy Chicken Si-won" & \\
c. "Ramadan Tahun Ini Berbeda" & "Mie Sukses's Kang Sule" & \\
Mie Sukses's & \\
\hline
\end{tabular}


Setelah peneliti melakukan observasi, kemudian peneliti melakukan penelusuran di internet mengenai ketiga iklan tersebut dan menemukan data penelitian dalam rekaman penelitian. Metode kualitatif dapat juga disebut metode metode dokumentasi.

Secara detail, peneliti dalam langkah pengumpulan data penelitian melakukan beberapa kegiatan. Pertama peneliti menentukan obyek penelitian, dalam hal ini iklan televisi mi instan pada saat pandemi Covid-19. Kedua, peneliti melakukan observasi kepada seluruh stasiun televisi. Ketiga, peneliti menentukan iklan yang akan diteliti sebagai data penelitian sesuai prosedur penelitian. Keempat, peneliti mencari dan mendokumentasikan data penelitian. Setelah data terkumpul, pengolahan data dilakukan dengan cara klasifikasi (mengklasifikasikan data berdasarkan fokus dan tujuan penelitian) dan analisis.

\section{HASIL DAN PEMBAHASAN}

Iklan merupakan produk komunikasi visual yang bertujuan untuk mempromosikan dan memersuasi khalayak agar mau membeli produk atau jasa yang diiklankan. Saat ini, media televisi bagi khalayak di Indonesia masih dianggap sebagai media yang paling ampuh untuk mempromosikan produk dan jasa dibandingkan media lainnya. Sesuai segi selektivitas dan fleksibilitas, televisi dapat menjangkau audiens tertentu dengan adanya variasi komposisi terkait isi program, waktu siaran, dan cakupan geografis (Haryadi, 2016).

Iklan dipercaya sebagai media massa yang masih setia digunakan sebagian besar khalayak Indonesia. Namun bagi sebagian orang, iklan merupakan salah satu siaran yang kurang disukai penonton apabila isi iklan tidak menarik, membosankan, atau terlalu panjang. Sejumlah riset tentang iklan menyebutkan bahwa jeda iklan umumnya digunakan penonton televisi untuk beranjak dari tempat duduknya untuk pergi ke toilet, pergi ke dapur untuk minum, atau melakukan aktivitas lainnya. Jeda iklan juga kerap digunakan penonton untuk mengambil remote control televisi dan membuka saluran televisi lainnya untuk mencari acara lain yang dianggap menarik. Oleh karena itu, siaran yang terlalu banyak iklan lebih sering ditinggalkan penonton daripada sebuah siaran yang iklannya sedikit (Haryadi, 2016).

Dengan demikian, adanya kecenderungan seperti di atas, para pengiklan berupaya agar iklannya dapat dilihat khalayak. Maka waktu penempatan kapan iklan itu harus muncul menjadi sangat penting. Iklan yang biasanya tertonton oleh khalayak adalah iklan pertama dan iklan terakhir saat jeda acara. Iklan yang masuk tiba-tiba itu akan tertonton, lalu penonton beranjak dari tempat duduk atau mencari saluran lain, dan kembali menjelang 
acara dimulai. Iklan terakhir pun terpaksa harus ditonton karena takut tertinggal acara yang sebelumnya ditonton.

Adapun upaya lainnya, iklan dibuat menarik dan unik. Salah satu caranya dengan membuat film iklan yang menampilkan public figure atau sosok yang dekat dengan khalayak tergantung dari khalayak mana yang akan dibidik dalam marketing produk yang diiklankan. Maka public figure yang semakin dikenal khalayak, akan semakin menarik sebuah iklan tersebut contohnya iklan Mie Sedaap yang berani menampilkan artis Korea Si-won sebagai bintang iklan.

Setiap merek iklan yang menggunakan public figure atau selebriti sebagai endorser memiliki beberapa keuntungan di antaranya, "Celebrity endorser memiliki kekuatan "menghentikan", celebrity endorser merupakan gambaran yang disukai atau dipuja, celebrity endorser memiliki karakteristik yang unik, dan celebrity endorser dianggap sebagai ahli yang berpengalaman di bidangnya (Gunawan, 2015). Kata lain, penggunaan endorser sejalan dengan format iklan The Celebrity-Spokeperson, atau menggunakan orang terkenal untuk “mempresentasikan" keunggulan produk yang diiklankan (Virga, 2019).

Ada dua keuntungan dalam menampilkan iklan yang menarik. Pertama, iklan akan memiliki daya tarik untuk ditonton. Kedua, tujuan promosi akan tercapai sehingga diharapkan orang akan membeli produk yang diiklankan. Berdasarkan alasan inilah banyak produk atau jasa yang baru muncul memerlukan promosi agar mereknya dikenal. Salah satunya menggunakan bintang iklan sosok yang sangat dikenal dalam masyarakat.

Iklan di televisi kadangkala tidak memerhatikan situasi dan kondisi masyarakat sebagai penontonnya. Maka terjadi benturan antara masyarakat dan televisi karena dianggap

Tabel 2 Belanja Iklan Televisi 2013 - 2019

\begin{tabular}{lll}
\hline No & Tahun & Nilai \\
\hline 1 & 2013 & Rp. 67,95 Trilyun \\
2 & 2014 & Rp. 75,3 Trilyun \\
3 & 2015 & Rp. 85,3 Trilyun \\
4 & 2016 & Rp. 103,8 Trilyun \\
5 & 2017 & Rp. 115,8 Trilyun \\
6 & 2018 & Rp. 93,8 Trilyun \\
7 & 2019 & Rp. 143 Trilyun \\
\hline
\end{tabular}


melanggar norma dan budaya suatu masyarakat. Sejak Komisi Penyiaran Indonesia (KPI) berdiri, sejumlah iklan televisi telah ditegur karena dinilai telah melanggar Pedoman Program Penyiaran (P3) dan standar penyelenggaraan siaran. Walaupun demikian, berdasarkan data Lokadata (2020), belanja iklan televisi masih meraup 80\% dari total belanja iklan di Indonesia. Bahkan, belanja iklan televisi cenderung naik dari tahun ke tahun.

Sesuai tabel 2, belanja iklan pada 2019 naik 10\% dibandingkan dengan 2018. Total belanja iklan pada 2019 baik di media televisi, radio, maupun cetak mencapai Rp. 168 triliun berdasarkan gross rate card. Televisi, masih mendominasi $85 \%$ porsi belanja iklan dengan angka lebih dari Rp. 143 triliun, tumbuh 14\% dibandingkan 2018. Sementara itu, belanja iklan di media cetak mencapai lebih dari Rp. 22 triliun dan total belanja iklan radio mencapai Rp. 1,7 triliun. Sepanjang tahun 2019, kategori layanan online menjadi penyumbang belanja iklan terbesar dengan total belanja iklan Rp. 10,3 triliun dan tumbuh 2\% (Nielsen.com, 2020).

Merek dalam industri refined food dengan belanja iklan televisi tertinggi yang berada di 2016, yaitu Indomie dengan total belanja iklan mencapai Rp. 1,08 triliun. Peringkat kedua adalah merek Sarimi dengan total belanja iklan Rp. 587 miliar. Adapun Mie Sedaap dan Pop Mie berada di peringkat ketiga dan keempat dengan masing-masing total belanja iklan mencapai Rp. 577 miliar dan Rp. 469 miliar. Sesuai data ini, terlihat bahwa mi instan Indomie banyak dibeli masyarakat Indonesia dibandingkan 3 merek lainnya.

Daya beli produk tentunya dipengaruhi iklan merek tersebut. Sesuai semiotika Barthes, iklan Indomie, Mie Sedaap, dan Mie Sukses's dapat dianalis ke dalam beberapa tahap, di antaranya denotasi, konotasi, dan mitos. Tahap pertama, denotasi yang dalam semiotika dikenal istilah penanda (signifier) dan petanda (signified). Barthes (2017) menggunakan istilah denotasi untuk signifikasi tahap pertama sebagai hubungan antara penanda dan petanda dalam sebuah realitas eksternal. Denotasi disebut sebagai makna paling nyata dari sebuah tanda.

Peneliti dalam penelitian ini melihat bahwa gambar (video) dan suara (audio) sebagai denotasi yang bisa dilihat dan didengar oleh siapa pun. Apabila ditinjau dari sisi denotasi, semua iklan mi instan yang dijadikan obyek penelitian secara visual memiliki perbedaan antara Indomie, Mie Sedaap, dan Mie Sukses's. Sesuai tampilan iklan, ada yang masih memutar iklan yang visualisasi iklan bergaya hura-hura, ada pula yang visualisasi iklan cukup hening tanpa hura-hura. Visualisasi iklan ketiga merek ini berbeda, ada yang bombastis dan boros kata, ada juga yang hemat kata. 


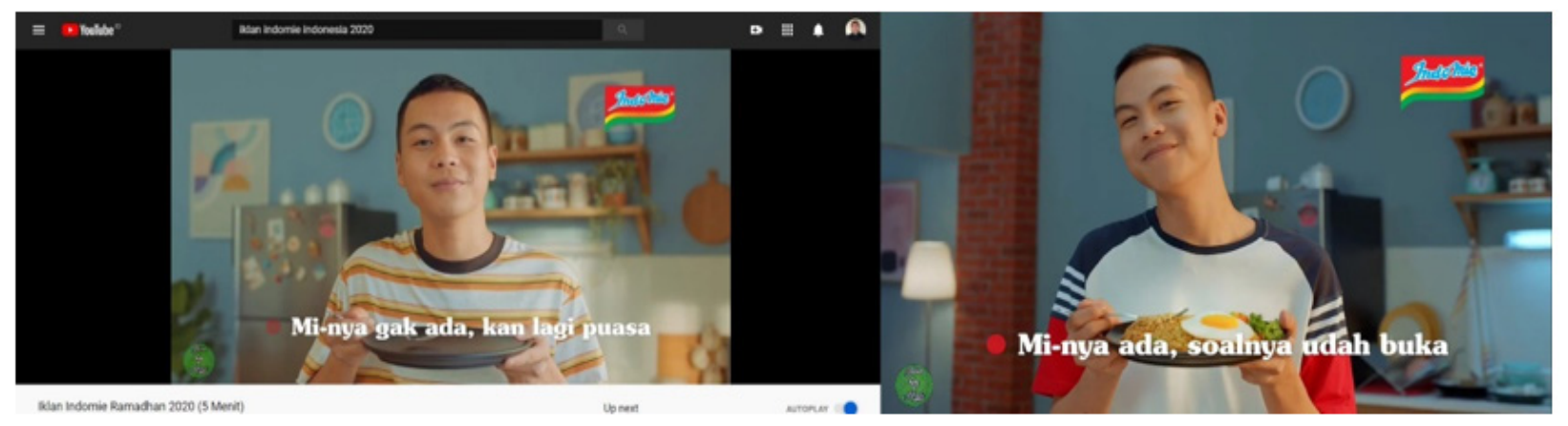

Sumber: Iklan 5 Menit, 2020

Gambar 1 Screenshot Iklan Indomie "Buka Puasa"

Bahasa dalam iklan dapat memiliki makna yang variatif. Bahasa dapat berupa sebuah tanda untuk melambangkan, mendukung atau merujuk sebuah objek, masyarakat dan peristiwa dalam dunia yang nyata (Prasetyo, \& Junaedi, 2020). Namun, pada umumnya makna bahasa iklan memiliki maksud untuk memersuasi khalayak menggunakan produk atau himbauan dari iklan tersebut (Putri \& Tressyalina, 2020). Lebih lanjut, bahasa adalah medium vital dalam memperkenalkan dan memengaruhi orang untuk membeli sebuah produk (Prasetya, Prayogi, \& Riadi, 2020).

Indomie merupakan merek mi instan yang sudah mapan dan menjadi mi instan nomor satu di Indonesia. Visualisasi iklan Indomie di televisi tidak terlalu bombastis namun sangat kreatif dalam mempertahankan daya ingat khalayak untuk tetap mengingat merek Indomie. Pada iklan Indomie edisi "Puasa" dan "Buka Puasa" (2020), Indomie membuat dua versi iklan yang mirip di mana adegan syuting di tempat dan pemeran yang sama. Edisi "Puasa" digambarkan tidak ada adegan makan mi, piring ditampilkan kosong, dan gambar mi pada kemasan Indomie pun kosong tanpa mi. Iklan Indomie ditampilkan sangat kreatif dalam memvisualkan suasana sepi saat pandemi dan puasa. Adapun pada edisi "Buka Puasa", visualisasi justru terbalik. Ada visualisasi hidangan mi dan kemasan Indomie muncul kembali gambar mi yang terhidang dalam piring. Ide vidualisasi iklan bertema Ramadan seringkali ditayangkan di bulan Puasa. Beberapa di antara iklan cukup bagus ialah iklan yang mengandung pesan penuh hikmah bagi para penonton (Andrianto, 2018). Iklan Indomie pada edisi "Nyaman di Rumah" yang ditayangkan April 2020, berdurasi 29 detik, sangat hemat kata. Adegannya hanya visualisasi rebusan mi dan adegan seorang lelaki muda yang sedang menyantap mi di mangkok sendirian di kamarnya, menggunakan celana pendek. Narasinya hanya, "Biar tenang, tarik nafaaaas... Indomie kuah hangatnya endeees... 


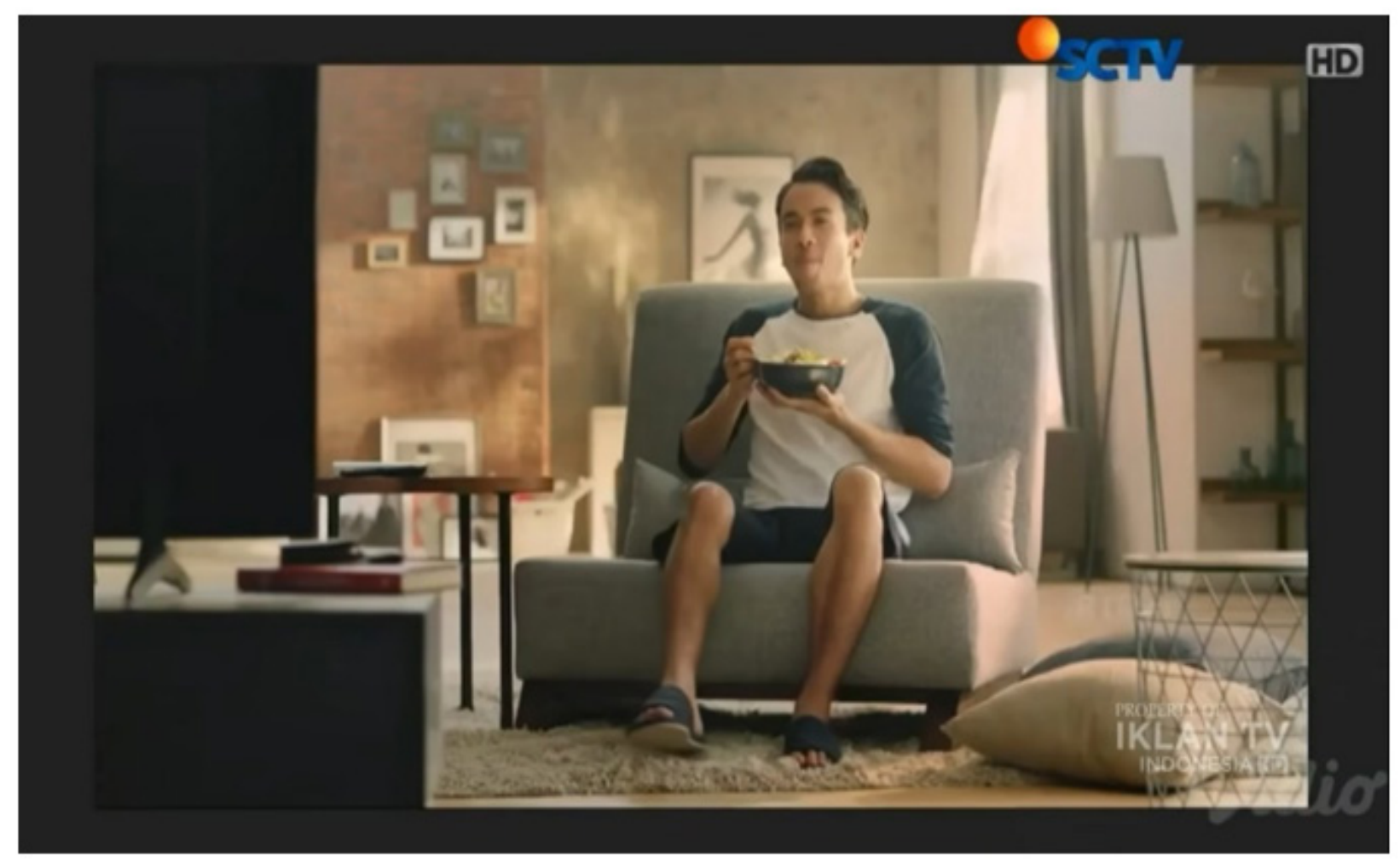

Sumber: Iklan TV Indonesia HD, 2020a

\section{Gambar 2 Screenshot Iklan Indomie "Nyaman di Rumah"}

Indomie kuah, bikin nyaman di rumah..."(Iklan TV Indonesia HD, 2020a).

Pada April 2020, Indonesia tidak memperbolehkan adanya kegiatan di luar rumah dan menerapkan bekerja di rumah atau Work From Home (WFH), belajar di rumah bagi semua siswa dan mahasiswa. Seluruh kawasan perumahan pun memberlakukan lockdown. Jika terpaksa ke luar rumah, masyarakat harus menggunakan masker, tidak ada aktivitas atau hiruk pikuk.

Indomie dapat memvisualkan kondisi bekerja atau belajar di rumah saat lockdown. Hal ini terlihat dari suasana kamar maupun dapur yang menunjukkan bahwa rumah tersebut bukan rumah sederhana, namun rumah golongan atas. Kendati kamar seorang lelaki muda, tetapi pengaturan kamar mencerminkan dari rumah golongan ekonomi atas. Begitu pun visualisasi dapur yang terkesan mewah, bersih, nyaman, dan memperlihatkan dapur dari rumah kalangan ekonomi atas.

Selanjutnya, iklan Mie Sedaap yang ditayangkan pada rentang waktu April dan Mei agak berbeda dengan iklan Indomie. Pada Maret hingga Mei, iklan Mie Sedaap masih menggunakan iklan lama yang ditayangkan di televisi dengan bintang drama Korea, Choi Siwon. Pada edisi “Ini Pilihan Sedaap-Ku”, secara denotatif, iklan berdurasi 42 detik menampilkan Choi Si-won dalam sebuah mobil bersama tiga temannya sedang bercengkrama, turun dari 


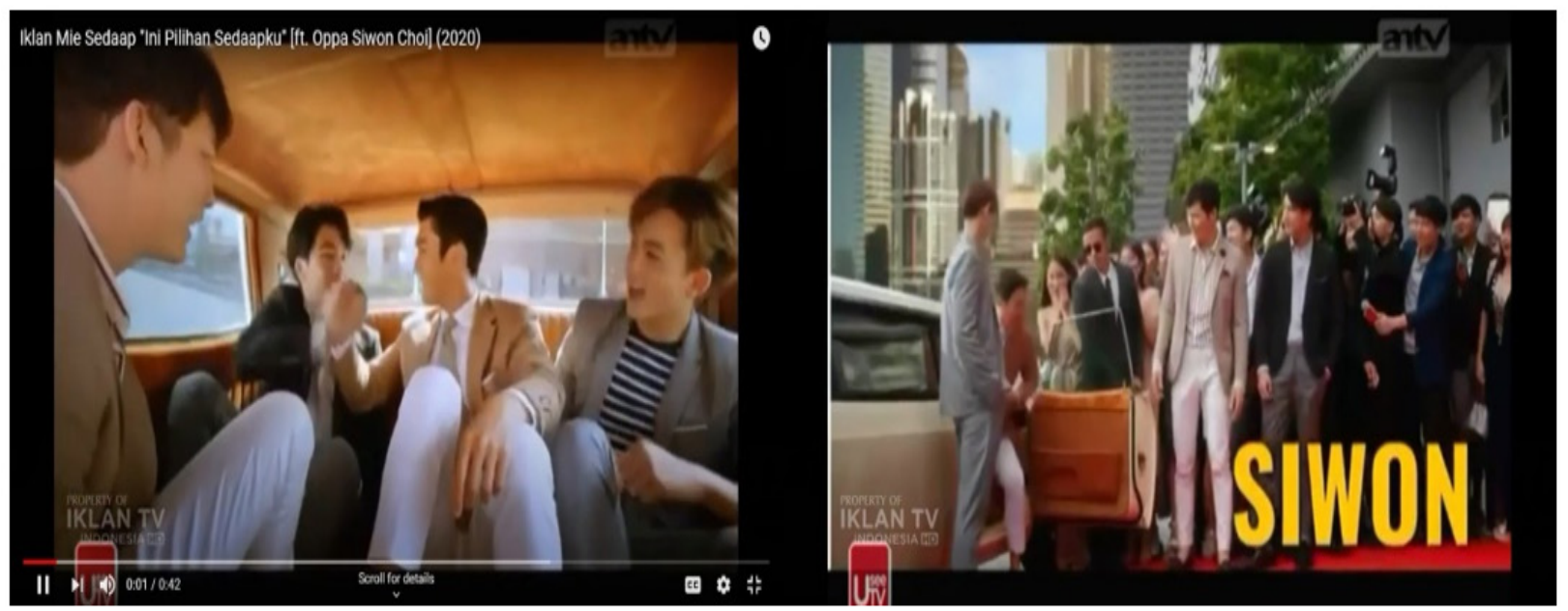

Sumber: Iklan TV Indonesia HD, 2020a

Gambar 3 Screenshot iklan Mie Sedaap "Ini Pilihan Sedaap-Ku”

mobil, lalu disambut belasan hingga puluhan orang (penggemar atau pers), dan muncul adegan makan Mie Sedaap. Narasi begitu begitu padat yang mendeskripsikan tentang aneka rasa dari sejumlah varian Mie Sedaap.

Pada edisi "Korean Spicy Chicken Siwon (Sadaab)", iklan 31 detik ini dimulai dengan visualisasi mi yang sedang direbus, di dalamnya ada telur, dan bahan pelengkap lainnya. Iklan ini tidak melibatkan tokoh lain, hanya Si-won seorang yang makan mi. Selain narator menerangkan tentang rasa dan varian Mie Sedaap, juga ada kata-kata: "[...] Fantastis, jelas menggoda. Pedasnya bisa diatur, mi-nya tebal wajib dijajal, Sadaab, sedaap mantab". Pemilihan kata-kata tersebut bertujuan untuk memengaruhi pembeli untuk membeli produk yang diiklankan; dan jenis bahasa yang sering digunakan dalam iklan adalah persuasif (Musaffak, 2015).

Pada iklan Mie Sedaap edisi "Ramadan Tahun Ini Berbeda", adegan visual dimulai
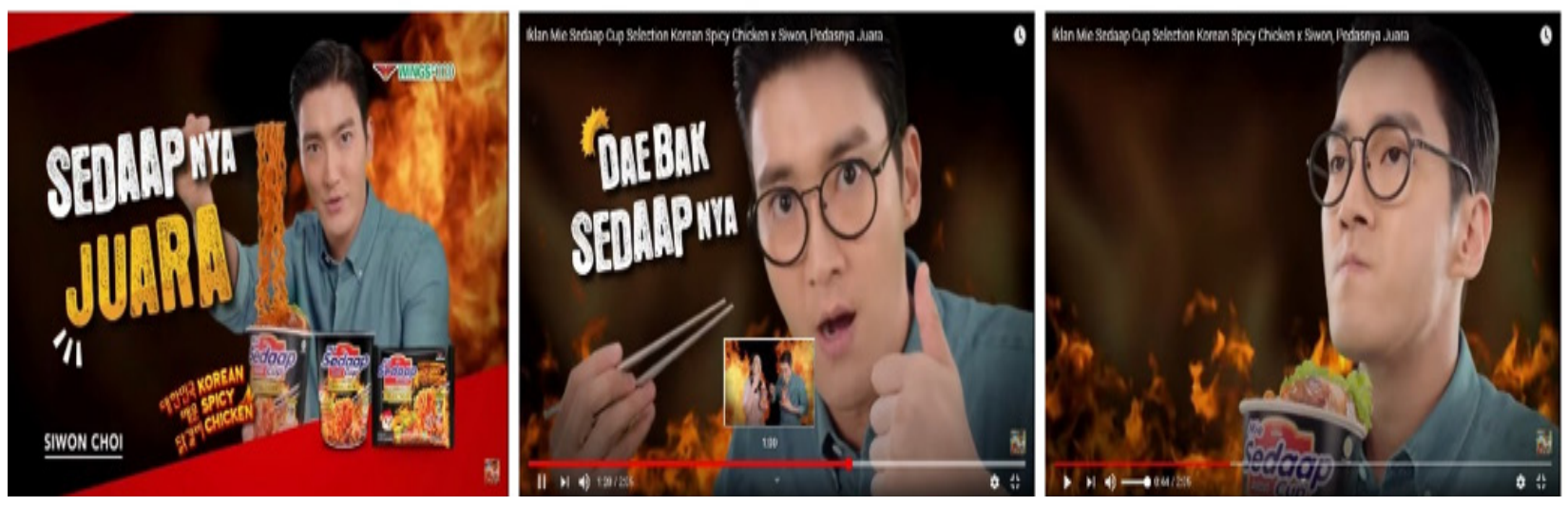

Sumber: Iklan TV Indonesia HD, 2020

Gambar 4 Screenshot iklan Mie Sedaap “Korean Spicy Chicken Si-won (Sadaab)" 
dengan beberapa remaja sedang bermain ammyfootball, lalu video sepasang remaja sedang makan mi di restoran (gambar hitam putih), sepasang remaja dewasa saling menelepon (hitam putih), seorang remaja perempuan yang tertidur di meja kerja terbangunkan oleh datangnya semangkuk Mie Sedaap. Visualisasi iklan diselang aneka varian Mie Sedaap, beberapa shot bergantian orang yang tengah makan mi, kembali ke visualisasi varian Mie Sedaap dengan narasi pendeskripsian rasa Mie Sedaap, kemudian ada pasangan remaja yang sedang menyantap mi. Video lalu diakhiri dengan kata "Ramadan Tahun Ini Berbeda".

Selain itu, iklan Mie Sukses's divisualisasikan berupa arak-arakan atau pesta di jalanan yang dipimpin oleh komedian Entis Sutisna (Sule). Puluhan orang bahkan mungkin ratusan orang terlihat menari bersama Sule sambil menyanyikan lagu tentang Mie Sukses’s. Iklan ini pun memvisualkan adegan menyantap mi secara massal. Narator terus mendeskripsikan tentang varian rasa dan kelezatan Mie Sukses's Isi 2 ini. Iklan diakhiri oleh still-picture dengan gambar Sule yang sedang menyantap Mie Sukses's di atas motor gede (moge) yang dihiasi lima varian rasa Mie Sukses's Isi 2 di bagian bawah.

Iklan Mi Sedaap dan Mie Sukses's lebih bombastis bahkan memperlihatkan suasana hiruk-pikuk di tengah pandemi Covid-19. Secara denotatif, iklan Mie Sedaap dan Mie Sukses's terlalu ramai dengan informasi tentang mi yang dipromosikan dengan banyak kalimat yang dilontarkan. Hal tersebut dilakukan dengan tujuan untuk menonjolkan "keunikan" dan "ciri khas" dari iklan tersebut. Sesuai keunikan dan ciri khas tersebut, sebuah iklan dapat menarik

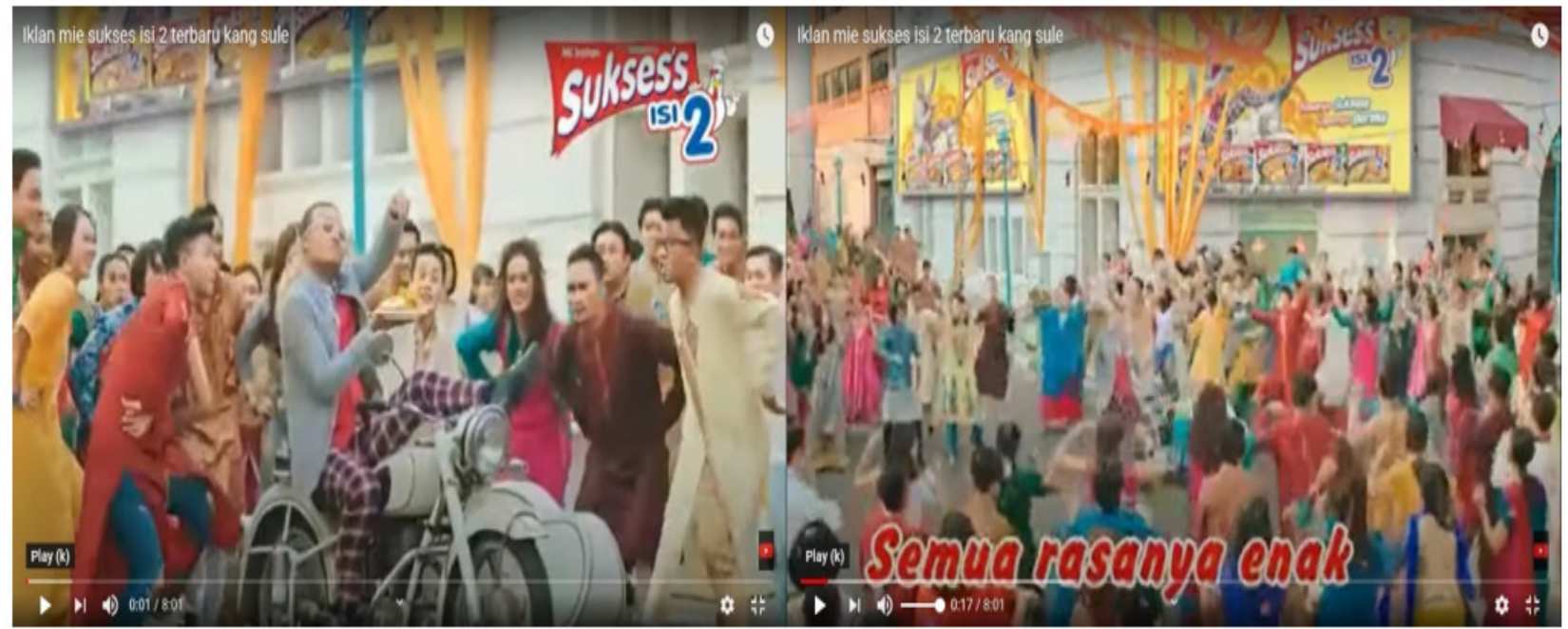

Sumber: youtube.com, 2020 
perhatian khalayak dan melekat di ingatan khalayak (Azmi \& Sarma, 2017).

Setelah tahap denotasi, tahap selanjutnya adalah tahap konotasi. Konotasi merupakan signifikasi tahap kedua setelah denotasi. Konotasi memvisualkan interaksi yang terjadi ketika tanda denotatif muncul ke hadapan benak dan emosi penonton disertai norma dan nilai budaya. Oleh karena itu, konotasi memiliki nilai yang subyektif atau intersubyektif.

Berdasarkan sisi konotatif, terdapat perbedaan konotasi antara Indomie dengan Mie Sedaap dan Mie Sukses's. Indomie memvisualkan iklan yang disesuaikan dengan situasi dan kondisi yang tengah berlangsung. Isi iklan dikondisikan bulan puasa yang tenang. Indomie pun memvisualkan suasana merebaknya Covid-19 yang mengharuskan semua orang berada di rumah. Aktor iklan dalam tampilan iklan Indomie hanya sendirian tanpa ada orang lain.

Pada awal masa pandemik di mana pemerintah menerapkan PSBB mulai pertengahan Maret dan masuk bulan suci Ramadan, Indomie menurunkan tiga iklan, di antaranya "Indomie Nyaman di Rumah", "Indomie Mi-nya Gak Ada", dan "Indomie Minya Ada". Tayangan iklan "Indomie Nyaman di Rumah" memunculkan konotasi bahwa di luar rumah sedang terjadi "sesuatu" sehingga sebaiknya orang berdiam di rumah. Visualisasi yang ditampilkan pun benar-benar suasana kamar, bukan rumah dan bahkan lelaki yang menyantap Indomie pun tidak menyantapnya di meja makan tetapi di kamar tidur dengan pakaian rumah, mengenakan celana pendek, dan kaos oblong. Persis seperti seseorang yang tengah diisolasi. Namun suasana menjadi nyaman karena pemeran iklan tersebut ditemani oleh Indomie.

Pemilihan bintang iklan yang berjenis kelamin laki-laki tentu didasari pertimbangan tertentu. Di era post-industrial, beberapa merek mencoba mencari pangsa pasar yang baru untuk dijadikan subjek dalam iklan. Tak sedikit yang beralih kepada kaum pria untuk dijadikan sebagai komoditinya, setelah sebelumnya kaum perempuan yang banyak dipilih (Pratami, \& Hasiholan, 2020).

Indomie pada Minggu ketiga bulan April 2020 saat memasuki bulan Ramadan, telah mengeluarkan dua iklan versi Ramadan, di antaranya "Indomie Mi-nya Gak Ada" dan versi "Indomie Mi-nya Ada". Iklan "Ga-ada Mi-nya" ditayangkan siang hari, dan "Ada Minya" ditayangkan malam hari. Tiap adegan iklan ditayangkan masing-masing 30 detik dan memiliki konotasi tentang "kesendirian". Adegan pemeran lelaki remaja di dapur juga ditampilkan sendirian. Iklan yang ditayangkan siang hari tidak menampilkan adegan makan mi karena mi ditampilkan tidak ada, 
sedangkan iklan yang ditayangkan malam hari memunculkan mi. Pada dua iklan ini, tidak ada orang lain yang menjadi pemeran, hanya berada sendiri di rumah.

Sementara itu, iklan Mie Sedaap dan Mie Sukses's secara konotatif telah melabrak suasana sosial yang tengah terjadi. Pesta dan hura-hura terlihat dalam visualisasi iklan yang hingar-bingar tanpa masker. Kendati sudah memasuki masa pandemi dan pemerintah sudah menerapkan PSBB, namun iklan Mie Sedaap masih menggunakan iklan yang diproduksi jauh sebelum itu. Selain itu, iklan baru versi Ramadan yang diproduksi di antaranya "Ini Pilihan Sedaap-Ku", "Korean Spicy Chicken Si-won", dan "Ramadan Tahun Ini Berbeda".

Mie Sedaap masih mengandalkan bintang drama Korea Choi Si-won. Pada "Ini Pilihan Sedaap-Ku” memunculkan makna konotasi bahwa pandemi Covid-19 tidak terjadi di Korea dan tidak diberlakukan PSBB atau lockdown karena Si-won dan kawan-kawan masih bercengkrama mulai dari mobil dia masih dicegat belasan wartawan yang mewawancarainya. Selain itu, iklan ini menampilkan arena hiburan yang masih dibuka terlihat dari visualisasi Si-won tampil di sebuah acara dalam sebuah gedung pertunjukan yang melibatkan banyak penonton.

Namun pemaknaan tahap kedua atau konotatif seperti itu tidak berlaku bagi penonton iklan yang lama. Hal ini karena iklan tersebut sudah diproduksi jauh-jauh hari sebelum pandemi dan PSBB diberlakukan. Namun penandaan dalam tahap kedua ini sama-sama memaknai bahwa Mie Sedaap disukai di Korea Selatan bahkan selebritis drama Korea pun menyukai Mie Sedaap.

Selain itu, ada perberbedaan edisi "Ini Pilihan Sedaap-Ku” dengan iklan Mie Sedaap versi “Korean Spicy Chicken Si-won”, di mana edisi "Korean Spicy Chicken Si-won" tidak melibatkan banyak pemain bahkan artis $\mathrm{Si}$ won cenderung tampil sendiri mempromosikan mi instan ini. Bahkan adegan edisi ini menggambarkan Si-won sedang berada di rumah. Konotasi yang muncul dari iklan ini adalah Mie Sedaap disukai oleh orang Korea, bahkan selebritis drama Korea sekaliber Siwon pun menyukai mi instan buatan Indonesia. Apabila dikaitkan dengan pandemi Covid-19, iklan ini tidak menggambarkan sesuatu yang bertentangan dengan PSBB karena menampilkan Si-won dalam kesendirian.

Adapun pada versi "Ramadan Tahun Ini Berbeda", kembali Mie Sedaap memperlihatkan keriuhan dan aktivitas remaja. Iklan ini sengaja dibuat untuk menyambut bulan Ramadan karena narasi dan visualisasi di akhir video memperlihatkan suasana Islami. Meski demikian, iklan di versi ini tidak mengurangi suasana PSBB di mana saat bulan Ramadan 
yang jatuh pada minggu ketiga April sampai Mei 2020 tengah gencar himbauan pemerintah agar semua orang diam berada di rumah.

Iklan berdurasi 30 detik ini terdiri dari banyak shot dan scene dengan durasi antara 2 sampai 3 detik yang menggambarkan aktivitas remaja. Setiap shot yang dilakukan bertujuan utnuk mengarahkan perhatian pada adegan dan pada objek yang memiliki arti dramatik terpenting (Iskandar, 2011). Iklan versi "Ramadan Tahun Ini Berbeda" dimulai dari adegan remaja pria dan perempuan yang janjian melalui telepon, sejumlah remaja bermain ammy-football, perempuan tertidur yang "dibangunkan" oleh aroma Mie Sedaap, sejumlah potongan visualisasi Mie Sedaap yang tengah dimasak, serta adegan pertemuan sepasang remaja laki dan perempuan di restoran. Iklan ini ditambah dengan narasi yang padat tentang varian Mie Sedaap dengan segala kelezatannya.

Gambaran isi iklan di atas, menganotasikan bahwa kendati di masa pandemi, aktivitas remaja tetap berlangsung di luar rumah. Mi instan ini seakan menjadi makanan untuk para remaja yang aktif di segala waktu, baik di bulan Ramadan maupun bulan lainnya dan pada saat pandemi maupun tidak. Namun, dalam iklan ini tidak ada visualisasi suasana Islami yang ditampilkan selain narasi bahwa saat itu bulan Ramadan dan ada sedikit ornamen di ujung iklan yang menegaskan bahwa saat itu suasana bulan suci.

Apabila dibandingkan dengan dua merek mi instan yang diteliti, Mie Sukses's memiliki frekuensi penayangan yang sangat jarang dan tidak dimunculkan pada saat primetime. Judul iklan yang menonjol pun hanya satu, yaitu "Mie Sukses 's Kang Sule”. Iklan yang dibintangi Sule ini diproduksi jauh sebelum pandemi Covid-19 merebak. Namun iklan ini tetap tayang kendati sudah memasuki masa pandemi. Bagi masyarakat yang tidak mengikuti atau tidak mengetahui keberadaan iklan ini sebelumnya maka dapat memunculkan persepsi yang kurang baik terhadap iklan ini.

Hal ini menjadi terasa sangat kontras di masa pandemi ketika semua orang mengisolasi diri di rumah namun dalam tayangan iklan pada layar televisi masih terlihat visualisasi pesta pora puluhan bahkan ratusan orang di jalanan. Para pemeran iklan menari dan menyanyi bersama (flashmob) sambal mengelu-elukan Sule yang naik motor gede (moge), dan pesta pun diisi dengan menyantap Mie Sukses's bersamaan. Narasi pun mengiringi visual yang menerangkan tentang varian dan rasa Mie Sukses's. Berdasarkan makna konotatif dari tayangan ini, pesta pora di jalanan tetap bisa berlangsung kendati Covid-19 tengah mewabah di seluruh penjuru dunia. Bagi orang yang memiliki daya literasi rendah, seperti anak-anak 
atau masyarakat yang baru menyaksikan iklan ini di masa pandemi aan menyiratkan bahwa pandemi tidak perlu ditakuti dan semua orang bisa berpesta pora secara massal.

Jingle atau nyanyian dari Sule menjadi daya tarik utama dari iklan Mie Sukses's ini. Kata lain, jingle yang berirama catchy dan kata-kata, slogan yang mudah diingat, ditambah pemilihan Sule sebagai bintang iklan menyiratkan harapan pihak produsen agar iklan ini dapat menempel di benak khalayak. Menurut survey yang dilakukan Harian Kompas di sepuluh kota di Indonesia, kurang lebih $70 \%$ responden mengaku gemar menirukan iklan yang ditayangkan di media, baik dalam meniru ucapan atau narasi, jingle atau lagu, gerakan hingga meniru sosok yang menjadi pemeran dalam iklan tersebut (Noor \& Wahyuningratna, 2017).

Berlanjut ke tahap mitos. Mitos dalam konteks semiotika Barthes (2017) merupakan pengkodean makna dan nilai-nilai sosial yang sesungguhnya memiliki sifat konotatif, namun mitos seringkali dianggap alamiah. Mitos merupakan sistem semiotika tahap kedua. Sebuah tanda dalam sistem pertama menjadi penanda pada sistem kedua. Jika bahasa obyek sebagai tanda, maka mitos berperan sebagai metabahasa. Mitos pun berfungsi untuk memberikan pembenaran berdasarkan budaya dominan (Barthes, 2017).

Berdasarkan visualisasi iklan Indomie, baik edisi "Nyaman di Rumah" maupun edisi Ramadan, ternyata memiliki makna kamar dan dapur milik orang dari golongan menengah ke atas atau orang "kaya". Mitos sebagai penanda dalam semiotika ini menggambarkan bahwa orang kaya takut dengan kehadiran pandemi Covid-19 sehingga memilih diam di rumah. Hal ini sesuai pesan yang muncul pada media sosial bahwa orang yang banyak terpapar Covid-19 adalah mereka dari golongan eknomi atas. Sebaliknya, pada orang miskin apalagi orang jalanan ternyata lebih kebal terhadap Covid-19 sedangkan orang kaya sangat rentan terhadap virus ini. Hal ini menunjukkan bahwa iklan mengondisikan sebuah kondisi dan situasi tertentu pada sebuah strata atau kelompok masyarakat (Nuraryo, 2019).

Adapun pada bulan awal pandemi Covid-19 merebak, sejumlah media sosial memberitakan Korea Selatan (Korsel) merupakan salah satu negara yang "aman" dari pandemi ini. Korban yang terpapar tidak sebanyak negara-negara lain. Korsel pun banyak dipuji orang (Ariyanti, 2020). Iklan Mie Sedaap yang sebetulnya sudah diproduksi jauh sebelum pandemi merebak makin memperkokoh mitos tersebut. Di mana dalam iklan tersebut aktivitas Si-won sebagai aktor drama Korea masih tetap aktif dalam dunia hiburan. Begitu pula visualisasi pada iklan episode Ramdan, masih tetap memperihatkan aktivitas remaja di luar rumah, baik itu sedang 
bermain ammy-football, aktivitas di restoran atau kafe yang tidak berubah.

Mitos dari iklan Mie Sedaap ini makin mengukuhkan bahwa Korea Selatan benarbenar negara yang berhasil mengatasi wabah Covid-19. Sesuai mitos dari iklan tersebut pun, dipersepsikan bahwa tidak ada larangan dari pemerintah Korea Selatan untuk semua warganya agar berdiam di rumah serta menerapkan protokol kesehatan, seperti menggunakan masker, menjaga jarak, mencuci tangan dan lain sebagainya.

Terakhir adalah mitos yang dibawa iklan Mie Sukses's. Sejak awal, Mie Sukses's memiliki pangsa pasar masyarakat kelas bawah. Frekuensi iklan televisinya pun hanya muncul sekali-kali, tidak sesering Mie Sedaap apalagi Indomie. Kendati iklan Mie Sukses's itu diproduksi jauh sebelum pandemi merajalela, namun masyarakat baru menonton iklan ini pada saat pandemi. Maka mitosnya adalah orang kalangan bawah itu aman dari Covid-19. Kemudian dipersepsikan bahwa virus tidak akan menghampiri masyarakat sehingga puluhan bahkan ratusan orang divisualisasikan melakukan pesta pora di jalanan bersama Sule.

Mitos pun menjadi sebuah sistem yang unik. Mitos dibangun melalui suatu rantai pemaknaan yang telah ada sebelumnya. Kata lain, mitos menjadi sangat kontekstual. Mitos dipengaruhi norma, budaya, berbagai situasi, dan kondisi dalam sebuah masyarakat. Mitos bisa disebarkan melalui media, di mana para kapitalis menyebarkan ideologi mereka melalui iklan di media (Djamereng, 2018). Iklan dibuat untuk mendorong orang senantiasa konsumtif dengan menciptakan pemaknaan pada benak khalayak dan mengkonstruksi masyarakat menjadi beberapa kelompok gaya hidup, di mana kehidupan mereka diatur berdasarkan

Tabel 3 Perbandingan Aspek Semiotika Barthes terhadap Iklan Mi Instan Indomie di Televisi

\begin{tabular}{cc}
\hline Aspek & Mi Instan Indomie \\
\hline Aspek Denotatif & $\begin{array}{c}\text { Memvisualkan suasana kamar dan dapur, menggambarkan rumah orang } \\
\text { dengan ekonomi kelas atas. Dapur terkesan mewah, bersih dan nyaman, yang } \\
\text { memperlihatkan dapur dari rumah orang "kaya". Iklan yang ditampilkan sangat } \\
\text { hemat kata dan tidak terlalu bombastis. }\end{array}$ \\
Aspek & $\begin{array}{c}\text { Visualisasi iklan disesuaikan dengan situasi dan kondisi yang tengah berlangsung. } \\
\text { Selain mengondisikan bulan puasa yang tenang, Indomie juga memvisualkan } \\
\text { Konotatif }\end{array}$ \\
suasana merebaknya Covid-19 yang mengharuskan semua orang ada di rumah. \\
Aktornya pun hanya sendirian.
\end{tabular}


Tabel 4 Perbandingan Aspek Semiotika Barthes terhadap Iklan Mi Instan Mie Sedaap di Televisi

\begin{tabular}{|c|c|}
\hline Aspek & Mi Instan Mie Sedaap \\
\hline Aspek Denotatif & $\begin{array}{c}\text { Narasinya sangat padat; mendeskripsikan tentang aneka rasa dari sejumlah } \\
\text { varian Mie Sedaap. Selain menggunakan Si-won sebagai endorser, iklan-iklan } \\
\text { Mie Sedaap juga banyak memperlihatkan aktivitas outdoor yang dilakukan para } \\
\text { remaja. }\end{array}$ \\
\hline $\begin{array}{c}\text { Aspek } \\
\text { Konotatif }\end{array}$ & $\begin{array}{l}\text { Memperlihatkan bahwa Mie Sedaap disukai di Korea Selatan, bahkan selebritis } \\
\text { drama Korea pun menyukai Mie Sedaap yang direpresentasikan oleh Choi } \\
\text { Si-won. Ditambah lagi, iklan Mie Sedaap menganotasikan bahwa kendati di } \\
\text { masa pandemi, aktivitas remaja tetap berlangsung di luar rumah. Mi instan ini } \\
\text { seakan menjadi makanan untuk para remaja aktif di segala waktu, baik di bulan }\end{array}$ \\
\hline $\begin{array}{l}\text { Aspek } \\
\text { Mitos }\end{array}$ & $\begin{array}{l}\text { Ramadan maupun bulan lainnya, pada saat pandemi maupun tidak. } \\
\text { Menunjukkan bahwa Korea Selatan benar-benar negara yang berhasil mengatasi } \\
\text { wabah Covid-19 ini. Tidak ada larangan dari pemerintahnya untuk semua } \\
\text { warganya agar berdiam di rumah dan menerapkan protokol kesehatan. }\end{array}$ \\
\hline
\end{tabular}

Sumber: Hasil Penelitian, 2020

Tabel 5 Perbandingan Aspek Semiotika Barthes terhadap Iklan Mi Instan Mie Sukses's di Televisi

Aspek

Aspek Denotatif

Aspek

Konotatif

Aspek

Mitos
Mi Instan Mie Sukses's

Sumber: Hasil Penelitian, 2020

tema, citra, dan makna simbolik tertentu

(Christinawati \& Junaidi, 2020).

Untuk memudahkan pembacaan, tabel 3 hingga tabel 5 adalah tabel komparatif analisis semiotika Roland Barthes terhadap iklan televisi Indomie, Mie Sedaap dan Mie Sukses’s.

\section{SIMPULAN}

Selama pandemi Covid-19, tiga merek mi instan gencar menayangkan iklan produknya di televisi, di antaranya Indomie, Mie Sedaap, dan Mie Sukses's. Secara denotatif, iklan Indomie memiliki visualisasi representasi dari masyarakat kalangan atas, memiliki hemat kata, dan tidak terlalu bombastis. Secara denotatif, Iklan Mi Sedaap dan Mie Sukses's lebih bombastis bahkan memperlihatkan suasana hiruk-pikuk di tengah pandemi Covid-19. Iklan 
Mie Sedaap dan Mie Sukses's terlalu ramai dengan informasi tentang mi yang dipromosikan dengan banyak kalimat atau narasi yang dilontarkan. Secara konotatif, iklan Indomie sesuai dengan kondisi ketika pandemi dengan fokus pada jargon "di rumah saja" sedangkan iklan Mie Sedaap dan Mie Sukses's sebaliknya menyiratkan bahwa meskipun sedang dalam kondisi pandemi, aktivitas outdoor masih bisa dilakukan dan pandemi Covid-19 tidak perlu ditakuti. Sesuai tataran mitos, iklan Indomie menggambarkan bahwa orang dengan tingkat ekonomi atas takut dengan Covid-19, iklan Mie Sedaap menggambarkan Korea Selatan berhasil mengatasi pandemi Covid-19, dan iklan Mie Sukses's menunjukkan bahwa orang dengan tingkat ekonomi bawah tidak akan terjangkit Covid-19. Alangkah baiknya apabila siaran iklan televisi di masa pandemi ini memunculkan adegan iklan yang mendukung kampanye pemberantasan Covid-19. Hal ini mengingat televisi saat ini masih menjadi media massa yang paling banyak digunakan oleh khalayak di Indonesia. Kendati hanya muncul sekitar setengah menit, iklan televisi pun sebaiknya tidak memberikan visualisasi yang tidak menguntungkan bagi kampanye nasional pemberantasan pandemi Covid-19. Maka, iklan televisi harus memberikan teladan bagi pemirsanya mengingat pandemi yang berlangsung hampir satu tahun ini belum memperlihatkan tanda-tanda akan mereda.

\section{DAFTAR PUSTAKA}

Andrianto, N. (2018). Pesan kreatif iklan televisi dalam Bulan Ramadan: Analisis semiotika iklan Bahagianya adalah Bahagiaku. Jurnal Studi Komunikasi, 2(1), 17-31. https://doi. org/10.25139/jsk.v2i1.336

Ariyanti, H. (2020). Cara Korea Selatan turunkan kasus Virus Corona COVID-19 tanpa lockdown. Liputan6.Com. Retrieved from https://www.liputan6.com/global/ $\mathrm{read} / 4202284 / \mathrm{cara}-\mathrm{k}$ orea-selatanturunkan-kasus-virus-corona-covid-19tanpa-lockdown

Azmi, F. N., \& Sarma, M. (2017). Pengaruh iklan televisi terhadap pengambilan keputusan pembelian konsumen es krim Magnum. Jurnal Manajemen Dan Organisasi, 8(2), 119-132. https://doi.org/10.29244/jmo. v8i2.19490

Barthes, R. (2017). Elemen-elemen semiologi. Jakarta: BasaBasi.

Christinawati, \& Junaidi, A. (2020). Standar kecantikan perempuan berhijab dalam iklan televisi: Analisa semiotika iklan Wardah versi Feel The Beauty. Prologia, 4(1), 209214. https://doi.org/10.24912/pr.v4i1.6477

Cobley, P., \& Jansz, L. (2010). Introducing semiotics: A graphic guide. Icon Books.

Denzin, N. K., \& Lincoln, Y. S. (2017). The SAGE Handbook of Qualitative Research (5th ed.). Thousand Oaks: SAGE Publications, Inc.

Djamereng, A. (2018). Analisis Semiotika pada iklan di televisi (Iklan Wardah dan iklan Total Almeera). Jurnal Al-Khitabah: Jurnal Komunikasi \& Penyiaran Islam, 4(1), 1-17. http://journal.uin-alauddin.ac.id/ index.php/Al-Khitabah/article/view/4713 
Gunawan, F. (2015). Efektivitas penggunaan Ashraf \& BCL sebagai celebrity endorser dalam iklan televisi LINE Let 's Get Rich dengan menggunakan model TEARS. Jurnal E-Komunikasi, 3(2), 1-10. http:// publication.petra.ac.id/index.php/ilmukomunikasi/article/view/4928

Haryadi, T. (2016). Analisis iklan televisi Sampoerna Hijau versi "Es Kacang Ijo" dengan pendekatan semiotika Roland Barthes. JADECS: Journal of Art, Design, Art Education \& Culture Studies, 1(1), 1-16. https://doi.org/10.17977/ um037v1i1p\%25p

Iklan 5 Menit. 2020, 1 Mei 2020. Iklan Indomie Ramadhan 2020 [Video]. YouTube. https://www.youtube.com/ watch? $\mathrm{v}=\mathrm{YMdSussNspo}$

Iklan TV Indonesia HD. 2020a, 1 April 2020. Iklan Indomie kuah "Nyaman di Rumah" (2020) [Video]. YouTube. https://www. youtube.com/watch? $=$ K5H74R4PQ6Y

Iklan TV Indonesia HD. 2020b, 1 Aapril 2020. Iklan Mie Sedaap "Ini Pilihan Sedaapku” [ft. Oppa Siwon Choi] (2020) [Video]. YouTube. https://www.youtube.com/ watch? $\mathrm{v}=67 \mathrm{FCsxHabXM}$

Iklan TV Indonesia HD. 2020c, 29 Maret 2020. Iklan Mie Sedaap selection Korean spicy soup "SADAAB" [ft. Oppa Siwon Choi] (2020) [Video]. YouTube. https://www. youtube.com $/$ watch? $\mathrm{v}=\mathrm{U} 6 \mathrm{rVk} 1 \mathrm{BmqpE}$

Indriani, S. S., Puspitasari, L., \& Rosfiantika, E. (2019). Analisis interaksi simbolik pada konten ofensif iklan Grab \#pilihaman. ProTVF: Jurnal Kajian Televisi Dan Film, 3(1), 81-100. https://doi.org/10.24198/ ptvf.v3i1.21245

Iskandar, M. S. (2011). Pembentukan persepsi visual pada iklan televisi. VISUALITA: Jurnal Online Desain Komunikasi Visual,
3(1), 14-33. https://doi.org/10.33375/vslt. v3i1.1095

Lokadata. (2020). Belanja iklan televisi, 2013-2019. Lokadata. Retrieved from https://lokadata.id/data/belanja-iklantelevisi-2013-2019-1585902307

Musaffak. (2015). Analisis wacana iklan makanan dan minuman pada televisi berdasarkan struktur dan fungsi bahasa. KEMBARA: Jurnal Keilmuan Bahasa, Sastra, Dan Pengajarannya, 1(2), 224 232. https://doi.org/10.22219/kembara. v1i2.2618

Nielsen.com. (2020). Belanja iklan 2019 ditutup dengan tren positif. Nielsen.Com. Retrieved from https://www.nielsen.com/ $\mathrm{id} / \mathrm{id} /$ press-releases/2020/belanja-iklan2019-ditutup-dengan-tren-positif/

Noor, F., \& Wahyuningratna, R. N. (2017). Representasi sensualitas perempuan dalam iklan New Era Boots di televisi: Kajian semiotika Roland Barthes. IKRAITH HUMANIORA: Jurnal Sosial Dan Humaniora, 1(2), 1-9. https://journals. upi-yai.ac.id/index.php/ikraith-humaniora/ article/view/140

Nuraryo, I. (2019). Kultur pop dan diskursus ideologi kecantikan pada iklan di televisi. ProTVF: Jurnal Kajian Televisi Dan Film, 3(2), 171-184. https://doi.org/10.24198/ ptvf.v3i2.21488

Permana, R. S.M.,Abdullah,A., \& Mahameruaji, J. N. (2019). Budaya menonton televisi di Indonesia: Dari terrestrial hingga digital. ProTVF: Jurnal Kajian Televisi Dan Film, 3(1), 53-67. https://doi.org/10.24198/ptvf. v3i1.21220

Prasetya, R. A., Prayogi, R., \& Riadi, B. (2020). Tindak ilokusi ekspresif dalam iklan makanan di televisi. JURNAL KATA: Bahasa, Sastra, Dan Pembelajarannya, 
8(1), 1-7. http://jurnal.fkip.unila.ac.id/ index.php/BINDO1/article/view/20893

Prasetyo, A., \& Junaedi, F. (2020). Representasi identitas muslimah dalam iklan televisi Sunsilk, Wardah, dan Emeron. Jurnal Interaksi: Jurnal Ilmu Komunikasi, 4(2), 203-218. https://doi.org/10.30596/ interaksi.v4i2.4532

Pratami, R., \& Hasiholan, T. P. (2020). Representasi maskulinitas pria dalam iklan televisi Men's Biore Cool Oil Clear. Jurnal Komunikasi, 14(2), 119-138. https://doi. org/10.20885/komunikasi.vol14.iss2.art2

Putri, S. Y., \& T. (2020). Strategi berbahasa dalam iklan minuman di televisi. LOGAT: Jurnal Bahasa Indonesia Dan Pembelajaran, 7(1), 15-23. https://doi. org/10.36706/logat.v7i1.304

Rosfiantika, E., Permana, R. S. M., \& Mahameruaji, J. N. (2020). Program live update pemberitaan risiko Covid-19 di televisi nasional Indonesia. ProTVF: Jurnal Kajian Televisi Dan Film, 4(2), 247-269. https://doi.org/10.24198/ptvf.v4i2.28758

Sandra, S., \& Setyabudi, D. (2020). Hubungan terpaan iklan di televisi dan kapabilitas brand ambassador dengan minat beli pada produk Mie Sedaap. Interaksi Online, 8(3), 1-9. https://ejournal3.undip.ac.id/index. php/interaksi-online/article/view/27968

Sari, W. (2020). Fenomena ekonomi politik komunikasi di Indonesia: Komodifikasi hijab pada dalam iklan Hijab Fresh Body \& Lotion di televisi. Jurnal Penelitian Pers Dan Komunikasi Pembangunan, 24(1), 1-11. https://doi.org/10.46426/jp2kp. v24i1.111

Savitri, N. W. (2017). Pengaruh celebrity endorser dan iklan melalui media televisi terhadap minat beli pada Tokopedia di
Denpasar. E-Jurnal Manajemen, 6(8), 4214-4239. https://ojs.unud.ac.id/index. php/Manajemen/article/view/31098

Sobur, A. (2017). Semiotika komunikasi. Bandung: Remaja Rosdakarya.

Sukmana, L. N., Achmad, G. N., \& ZA, S. Z. (2017). Pengaruh efektifitas iklan televisi. Jurnal Manajemen, 9(2), 76-84. https:// doi.org/10.29264/jmmn.v9i2.2477

Umarela, F. H., Dwityas, N. A., \& Zahra, D. R. (2020). Representasi ideologi supremasi kulit putih dalam iklan televisi. ProTVF: Jurnal Kajian Televisi Dan Film, 4(1), 64-84. https://doi.org/10.24198/ptvf. v4i1.25172

Virga, R. L. (2019). Representasi gaya hidup wanita muslim Indonesia dalam iklan televisi. PANANGKARAN: Jurnal Penelitian Agama Dan Masyarakat, 2(2), 207-218. https://doi.org/10.14421/ panangkaran.2018.0202-02

Worotitjan, H. G. (2014). Konstruksi kecantikan dalam iklan kosmetik Wardah. Jurnal E-Komunikasi, 2(2), 1-10. http:// publication.petra.ac.id/index.php/ilmukomunikasi/article/view/1787

Wulandari, D. (2019). 2018, Belanja iklan TV capai Rp 110,46 triliun - MIX Marcomm. Marketing Communication. Retrieved from https://mix.co.id/marcomm/newstrend/2018-belanja-iklan-tv-capai-rp11046-triliun/

Yuliyanti, F. D., Bajari, A., \& Mulyana, S. (2017). Representasi maskulinitas dalam iklan televisi Pond's Men \#lelakimasakini: Analisis semiotika Roland Barthes terhadap representasi maskulinitas. Jurnal Komunikasi, 9(1), 16-30. https://doi. org/10.24912/jk.v9i1.180 